\title{
Tripartite Motif-Containing Protein 16
}

National Cancer Institute

\section{Source}

National Cancer Institute. Tripartite Motif-Containing Protein 16. NCI Thesaurus. Code C106035.

Tripartite motif-containing protein 16 (564 aa, $\sim 64 \mathrm{kDa}$ ) is encoded by the human

TRIM16 gene. This protein is involved in histone acetylation, keratinocyte differentiation and retinoic acid signaling. 